\title{
Relationships among open innovation, innovative performance, government support and firm size: Comparing Brazilian firms embracing different levels of radicalism in innovation
}

\author{
Daniel Jugend ${ }^{\mathrm{a}, *}$, Charbel Jose Chiappeta Jabbour ${ }^{\mathrm{b}}$, Janaina A. Alves Scaliza ${ }^{\mathrm{a}}$, Robson Sø Rocha ${ }^{\mathrm{c}}$, \\ José Alcides Gobbo Junior ${ }^{\mathrm{a}}$, Hengky Latan ${ }^{\mathrm{d}}$, Manoel Henrique Salgado ${ }^{\mathrm{a}}$ \\ a Department of Production Engineering, Sao Paulo State University - UNESP, Av. Engenheiro Luiz Edmundo Carrijo Coube 14-01. PO BOX 17033-360, Bauru, SP, Brazil \\ ${ }^{\mathrm{b}}$ Montpellier Business School, Montpellier Research in Management, 2300, avenue des Moulins, 34185 Montpellier Cédex 4, France \\ c Department of Management, Århus University, Fuglesangs Allé 4 2628, M306, 8210 Aarhus, Denmark \\ d Department of Accounting, STIE Bank BPD Jateng, Jl. Pemuda No 4 A, Semarang 50139, Indonesia
}

\section{A R T I C L E I N F O}

\section{Keywords:}

Innovation

Open innovation

Structural equation modeling

Collaboration

Emerging economies

\begin{abstract}
A B S T R A C T
This work extends knowledge concerning the relationships among open innovation, innovative performance and government support for innovation within Brazilian firms. Data were obtained from two different firm samples (Sample A, on incremental innovation, and Sample B, on radical innovation). The main research results are as follows. First, in considering government support for innovation, Sample B, based on radical innovation, played a superior and stronger role than Sample A. Secondly, for both samples, the cooperation of external firms has a positive effect on firms' innovative performance, which was positively controlled by the size of the firms. Thirdly, in general, radical innovation requires synergy and a more intense focus regarding the constructs considered therein. This work also adds value in methodological terms, as this is the first research to have tested different models of samples with different levels of radicalism in innovation.
\end{abstract}

\section{Introduction}

This article aims to answer unresolved questions concerning open innovation (OI), as well as its impact on both incremental and radical innovation performance. What are the effects of internal and external organizational boundary collaboration on these two forms of innovation performance respectively? What moderating role does government support play in the relationship between internal and external organizational boundary collaboration and radical and incremental innovation performance?

Because of its potential to intensify internal and external knowledge flows in order to improve the process of innovation, the OI approach proposed by Chesbrough (2003b) has attracted attention from professionals and researchers concerned with the topics of innovation and technology management (e.g., Laursen and Salter, 2006; Trott and Hartmann, 2009; Randhawa et al., 2016). Several publications seek to demonstrate the main practices that companies operating in different countries and economic sectors adopt in order to operationalize OI (Van de Vrande et al., 2009; Cheng and Huizingh, 2014). Other studies show the influence of relationships between the application of OI practices and firm performance (Burcharth et al., 2014; Greco et al., 2015; Rubera et al., 2016). However, conclusions regarding the nature of the relationship remain uncertain (Cheng and Shiu, 2015). There is a lack of research analyzing and comparing the boundaries of collaboration and their influence on radical and incremental innovation. In addition, a lesser-known aspect is government support and its moderating role in the relationship between organizational boundary collaboration and innovation performance.

Drawing a comparison between companies that have developed incremental and radical innovation respectively is justified because studies in innovation management (e.g., Chang et al., 2012; Cheng and Shiu, 2015; Inauen and Schenker-Wicki, 2015) have shown that these two forms of innovation effort require different management practices, capabilities and organizational components (Bessant et al., 2010; Büschgens et al., 2013; Salter et al., 2014b). We will refer to internal and external organizational boundary collaboration as simply internal collaboration (IC) and external collaboration (EC).

In view of these gaps, to address the lack of literature with respect to this subject, the objective of the present article is to address the influence of organizational boundary collaboration on innovation

\footnotetext{
* Corresponding author.

E-mail addresses: daniel@feb.unesp.br (D. Jugend), c.chiappetta-jabbour@montpellier-bs.com (C.J.C. Jabbour), janainaalvesscaliza@hotmail.com (J.A. Alves Scaliza), rocha@mgmt.au.dk (R.S. Rocha), gobbo@feb.unesp.br (J.A.G. Junior), latanhengky@gmail.com (H. Latan), henri@feb.unesp.br (M.H. Salgado).
} 
performance in companies with both radical and incremental innovation, as well as in companies with incremental innovation alone. In addition, the study aims to verify the moderating role of government support and company size in innovation performance in an emerging market environment. To achieve this objective, a quantitative survey was conducted of a sample of 116 firms belonging to innovative sectors in Brazil (IBGE, 2013), such as electronics, industrial automation and telecommunications. Of these firms, 63 declared that they developed only incremental innovations (Sample A), while 53 firms declared that they have developed radical innovations (Sample B).

Furthermore, research on this topic is almost exclusively based on studies of North American, European and Asian firms (e.g., Chesbrough, 2003a; Van de Vrande et al., 2009; Cheng and Huizingh, 2014). Few studies have been published on this topic on firms operating in Brazil (Nagano et al., 2014) and fewer still in South America as a whole. Brazil invests a superior percentage of its gross domestic product (GDP) in activities related to R\&D when compared with other Latin American economies, but it performs poorly in relation to developed countries when data related to the number of patents are taken into account (Esteves and Feldmann, 2016). In analyzing this divergence, one notices that technology acquisition is the most important innovation strategy in Brazil. Overall, locally-based firms are considered to be more innovative in terms of processes innovation than in new product innovation, which tends to require highly skilled and qualified workforce (Goedhuys and Veugelers, 2012). Another possible explanation for this situation is that the economic sectors in which Brazil specializes are in the commodity industries.

Government economic intervention intended to foster OI and growth was also an integral part of a national project involving public policies implemented by several government agencies in Brazil. Rocha (2009) and Lisboa and Latif (2013) argue that the Brazilian government's interventions aim to protect the national industry and have been viewed as a mechanism to induce economic development through import substitution strategies and quotas for local content. In addition, more recently, the Brazilian government has stimulated technological innovation and a more open ecosystem for innovation in the country through specific laws involving public incentives for innovation, such as the Innovation Law (Matias-Pereira and Kruglianskas, 2005; Fabiani and Sbragia, 2014). We therefore had an opportunity to assess whether or not government intervention truly plays a role in the different types of innovation performance.

To address these issues, this article first presents its theoretical model and research hypotheses. Second, it presents and justifies the methodological procedures used in this study. Third, the results from the companies that participated in this survey are presented. Fourth, a discussion of the implications, conclusions, limitations and future research proposals is provided.

\section{Conceptual background}

\subsection{Incremental and radical innovation and open innovation}

Baregheh et al. (2009) define innovation as a multi-stage process in which organizations turn ideas into new or improved products, service or processes in order to advance, compete and differentiate themselves in their market place. Innovations may require different efforts and can therefore be classified using a typology (Mol and Birkinshaw, 2014). Two basic types of technological innovation can be distinguished (Van de Ven et al., 2000; Garcia and Calantone, 2002; Bessant et al., 2010): incremental and radical (or continuous and non-continuous). Incremental innovation can be characterized by improvements leading to minor technological changes, causing a minor differential in the value realized by the customer. Radical innovation incorporates a substantially different technology and fulfills novel emerging customer needs (Van de Ven et al., 2000; Forés and Camisín, 2016).

Previous work (e.g., Teece, 2007; Salter et al., 2014b) suggests that incremental and radical innovations require the adoption of different management practices and capabilities. For Veryzer (1998) and Bessant et al. (2014), it is not clear whether management practices associated with incremental innovations are similarly applicable to radical innovations, or whether certain traditional practices may prove unproductive in the context of radical innovations. The results of research by Fóres and Camisón (2015) indicate that large companies are focused on incremental innovation rather than radical innovation. According to these authors, this focus occurs because large firms often seek to solidify their market positions and therefore apply incremental innovations more frequently. This finding does not mean that small companies are focused on high growth sectors, but the stronger evidence for innovation originates from small, young, high-growth, companies (Mazzucato, 2011).

OI activities have an inconclusive impact on incremental and radical innovation performance (Cheng and Shiu, 2015; Greco et al., 2015). Tödtling et al. (2009) found that firms that introduce radical innovations cooperate more often with external linkages, such as universities and research organizations, while those that have introduced less advanced innovations rely more on internal linkages. Firms with OI strategies tend to combine technology exploration and exploitation (Van de Vrande et al., 2009). Gobbo Junior and Olsson (2011) suggest that, while exploration involves radical innovation, exploitation involves incremental innovation in which strong ties are needed to support the exploitation of innovations, leading to strong internal collaborative activities.

Compared to incremental innovations, the development of radical innovation requires more intense application of organizational components, such as cross-functional development teams, organizational structures oriented towards innovation and the involvement of senior management in the innovation process, among other aspects (Mol and Birkinshaw, 2014; Büschgens et al., 2013; Salter et al., 2014b). Because of the need to transform invention into development, the integration of different functions of the organization is a relevant aspect of the development of radical innovations (Griffin et al., 2014).

Despite these differences, few studies compare radical and incremental innovation efforts with the collaborative relationships proposed by the OI approach. One of these studies, by Chang et al. (2012), found that openness capability, or the firm's ability to search for diversified sources of creative ideas from external, distant and wider orientations, increases radical innovation performance. Chiang and Hung (2010) noted that, while a limited number of external channels can facilitate incremental innovation, the broad range of external channels can enhance the innovating firm's radical innovation performance. Inauen and Schenker-Wicki (2015) recognize that inside-out OI has a significant impact on innovation performance and is more likely to create radical innovations.

Cheng and Shiu (2015) found that a company's ability to obtain and exploit the knowledge of external partners enhances its radical innovation performance. However, this situation hinders the company's incremental innovation performance. Rubera et al. (2016) found that, when complemented by market information and the strong involvement of the R\&D department, OI practices positively influence the number of new-to-firm products that firms develop and introduce to markets.

\subsection{Internal and external collaboration and open innovation}

OI has been researched from several perspectives (Oakley, 2012; Randhawa et al., 2016), industrial contexts (Ozman, 2012) and using different levels of analysis (Bogers et al., 2017). Therefore, Bogers et al. (2017) propose a theoretical framework that compares the five levels of analysis in OI. Considering the objectives of this research, we investigated the following levels of analysis: intra-organizational (issues such as employee participation and organizational culture in OI activities), and extra-organizational (addressing the involvement of external 
stakeholders in the innovation process).

From the perspective of the extra-organizational level of analysis, West and Bogers (2014) suggest that companies can identify or search for external sources of innovation by collaborating with a diverse group of external stakeholders or by seeking experts with valuable knowledge (i.e., external collaboration). Jones et al. (2016) highlight the role of external partnerships as one of the main trends in OI. With respect to integration with the external environment, studies show that OI is based on strengthening collaborative relationships for innovation with suppliers, customers and users, universities, government research institutes, consultants and competitors (Von Hippel, 1986; Piller and Walcher, 2006; Huizingh, 2011; Holl and Rama, 2012). Chen et al. (2011) note that firms increasingly rely on knowledge from external sources to strengthen and accelerate their internal innovations. Ritala et al. (2015) suggest that external knowledge-sharing is positively associated with innovation performance.

From the perspective of the intra-organizational level of analysis, in addition to senior management's support for employees' involvement in the innovation process (Markham and Griffin, 1998; Nonaka and Von Krogh, 2009), it is important to promote the creation of ideas and the integration of knowledge that are internal to the firm (Markham and Griffin, 1998; Rocha, 2010), that is, internal collaboration. Love et al. (2011) noted the importance of internal collaboration in the innovation process, especially the multi-functional work in the acquisition and abstraction of ideas and solutions that are external to the company.

In addition, for the suitable performance of internal collaboration for innovation, it is important that employees are involved in the innovation process to strengthen the focus of organizational culture in innovation (Büschgens et al., 2013; Hosseini et al., 2017), as well as to mitigate the impact of the Not Invented Here (NIH) syndrome, which is recognized by many as one of the main factors preventing the adoption of the OI approach (Lichtenthaler and Ernst, 2006; Burcharth et al., 2014).

Given that a significant problem associated with the application of OI is the disclosure and transfer of important internal knowledge from companies to external actors (Inauen and Schenker-Wicki, 2015), described by Laursen and Salter (2014) as the paradox of openness, several studies suggest that collaborative relationships between innovative companies and various stakeholders can generate various benefits. These relationships include access to other organizations' capabilities, the co-development of ideas, the creation and improvement of new services, products and processes, the reduction in risks associated with the development of technologies and decreased R\&D costs, among others (Spithoven et al., 2010; Huizing, 2011).

From these arguments, it is understood that internal collaboration favors the establishment of external collaborative relationships in incremental and radical innovation environments. Therefore, the following hypotheses are proposed:

H1a. Internal collaboration (IC) has a positive relationship with external collaboration (EC) in firms focusing on incremental innovation.

H1b. Internal collaboration (IC) has a positive relationship with external collaboration (EP) in firms focusing on radical innovation.

\subsection{Innovation performance}

Despite the existence of many studies that have analyzed the relationship between OI and performance (Laursen and Salter, 2006; Cheng and Shiu, 2015), works such as those by Huizingh (2011), Ritala et al. (2015) and Cheng and Shiu (2015) have advocated the need to increase the number of studies evaluating the relationship between the adoption of OI practices and company performance. For example, Laursen and Salter (2006), Stam (2009), Gassmann et al. (2010), Sofka and Grimpe (2010), Hung and Chou (2013), Cheng and Huizingh
(2014) and Kim et al. (2016) have all verified the relationship between the adoption of OI practices and operational and innovative performance.

Understanding that innovative performance has a wide variety of indicators, Hagedoom and Cloodt (2003) broadly defined innovative performance, with focuses on both the technical aspects of innovation and the introduction of new products into the market. Laursen and Salter (2006) showed that companies that are more open tend to improve their innovative ability. Previous research (e.g., Sofka and Grimpe, 2010; Greco et al., 2015) also suggests that collaboration can increase knowledge-sharing and the creation of new knowledge.

Chen et al. (2011) note that increasing the diversity of external partners improves a firm's innovative performance, up to an optimal number of partners; thereafter, openness becomes counterproductive. In the context of new product development, the study by Knudsen and Mortensen (2011) observed that increasing openness leads to a longer time to market and increases the cost of product projects. Parida et al. (2012) found that the adoption of OI activities can positively influence the innovative performance of high-tech small and medium-sized firms. Hung and Chou (2013) noted that the acquisition and use of technologies from outside renews and broadens firms' knowledge and performance. Breunig et al. (2014) found evidence that higher levels of innovative performance for OI mainly depend on the company's collective effort in implementing OI. This suggests that no conclusions can be drawn regarding the relationship between OI and innovative performance and that this requires further studies (Cheng and Shiu, 2015).

Given these arguments, we understand that it is relevant to advance knowledge regarding IC and EC, incremental and radical innovation collaborations, and innovative performance. In addition, IC and EC are expected to favor innovative performance. Thus, the following hypotheses are proposed:

H2a. Internal collaboration (IC) has a positive relationship with innovative performance (IP) in firms focusing on incremental innovation.

H2b. Internal collaboration (IC) has a positive relationship with innovative performance (IP) in firms focusing on radical innovation.

H3a. External collaboration (EC) has a positive relationship with innovative performance (IP) in firms focusing on incremental innovation.

H3b. External collaboration (EC) has a positive relationship with innovative performance (IP) in firms focusing on radical innovation.

\subsection{Government support}

Mazucatto (2011) argues that, in order to foster a post-crisis recovery, state policies and public investment should be used to unleash entrepreneurship and innovation in the private sector. Examples of the high-tech sector in the USA show that the most innovative young companies received financial support from public investment. Correspondingly, the state is more likely to invest in physical and human infrastructure than individuals and business enterprises are, due to a combination of the required amount of fixed costs and the degree of uncertainty generated by such investments in innovation (Mazzucato, 2011). Government support for firms can assume different forms, such as grants, tax incentives, state-sponsored labs or direct investment through public venture capital.

The literature suggests that government support directly and indirectly affects firms' innovation by stimulating internal R\&D, IC and EC (Cano-Kollmann et al., 2017; Holl and Rama, 2012; Kang and Park, 2012). Government support for innovation is becoming more diffused due to innovation policies supporting networks of innovators (Caloffi et al., 2015). Research conducted with companies operating in Brazil indicates that the government's stimulus for companies to innovate 
influences their innovation performance (Etzkowitz et al., 2005; Matias-Pereira and Kruglianskas, 2005; Fabiani and Sbragia, 2014).

However, public funding and government support for innovation is not the only avenue for promoting innovation (Savage, 2015), a subject requiring more research. Thus, we have included government support as a moderating variable based on the judgment that it is probably moderation that strengthens the relationship between variables. The testing of moderation effects will be useful for capturing more complex phenomena and reducing the biases in conclusions. This kind of testing is needed to avoid the risk of Type I error. The government's support will strengthen the relationship between variables (IC and EC) and IP. Therefore, the following hypotheses are proposed:

H4a. The relationship between internal collaboration (IC) and innovative performance (IP) becomes stronger with government support in firms focusing on incremental innovation.

H4b. The relationship between internal collaboration (IC) and innovative performance (IP) becomes stronger with government support in firms focusing on radical innovation.

H5a. The relationship between external collaboration (EC) and innovative performance (IP) becomes stronger with government support in firms focusing on incremental innovation.

H5b. The relationship between external collaboration (EC) and innovative performance (IP) becomes stronger with government support in firms focusing on radical innovation.

Fig. 1 shows the models that were tested in this research. Model 1 is oriented to firms focusing on incremental innovation, while Model 2 embraces a more radical innovation context. Based on the arguments from the literature reviewed above, it is reasonable to assume that there are some differences between Model 1 and Model 2.

In addition, firm size can be considered a control variable in innovative processes because previous studies show that firm size may affect innovation performance (e.g., Stam, 2009; Cheng and Huizing, 2014; Ritala et al., 2015). The commonly held assumption is that 'small firms' matter for innovation (Teirlinck and Spithoven, 2013); hence, they matter for the many different public policies and the support that targets these companies.

\section{Research design}

For the purposes of data collection, a pilot study was conducted to assess validity. A structured questionnaire was drawn up to assess the intensity of interviewees' agreement or disagreement with each question. To evaluate the questionnaire before it assumed final form, the research team sent it to three professors whose research was in innovation and technology management, two of them working in universities in Europe, the third in a Brazilian university. In addition, the questionnaire was sent to a Brazilian executive who works in the field of industrial automation projects. The following paragraphs explain how the statements used in this questionnaire were constructed. The interviewed sample reported no difficulties in completing the questionnaire.

\subsection{Measurements}

Following the propositions of Laursen and Salter (2006), Huizing (2011), and Laursen and Salter (2014), the potential for collaboration by the following stakeholders during the innovative processes was measured through suppliers, customers, universities, the competition, government, research institutes and consultants. Each of these categories was measured using a 7-point Likert scale ranging from 1 (no collaboration) to 7 (very intense collaboration). To measure internal collaboration, this study was based on the following assertions: employee practices involving participation in the company's innovation activities (Chesbrough, 2003a; Van de Vrande et al., 2009; Samson and Gloet, 2015); the use of cross-functional teams with engineering, R\&D, marketing and production representatives, for example, for the integrated development of innovations (Love and Roper, 2009; Chiaroni et al., 2011; Nagano et al., 2014); and whether the company has clear procedures and policies for the participation of its employees in creating or proposing innovations (Markham and Griffin, 1998; Lindegaard, 2010; Chiaroni et al., 2011). Each of these items was measured using a 7-point Likert scale ranging from 1 (totally disagree) to 7 (totally agree).

According to the Oslo Manual proposal (OECD, 2005) and research by Nassimbeni (2003), a company's innovative performance can be reflected in the new products and services it has launched, the innovations to processes and services that have been implemented, new ways to meet market demand and new ways to organize and manage work. Thus, based on the studies by Krause et al. (2001), Nassimbeni (2003) and Ritala et al. (2015), innovative performance was measured in terms of the quantity of developed and launched products and services, the number of applications of new technologies and innovation in the production and service processes, and new ways to organize and manage the work. Each of these items was measured using a 7-point
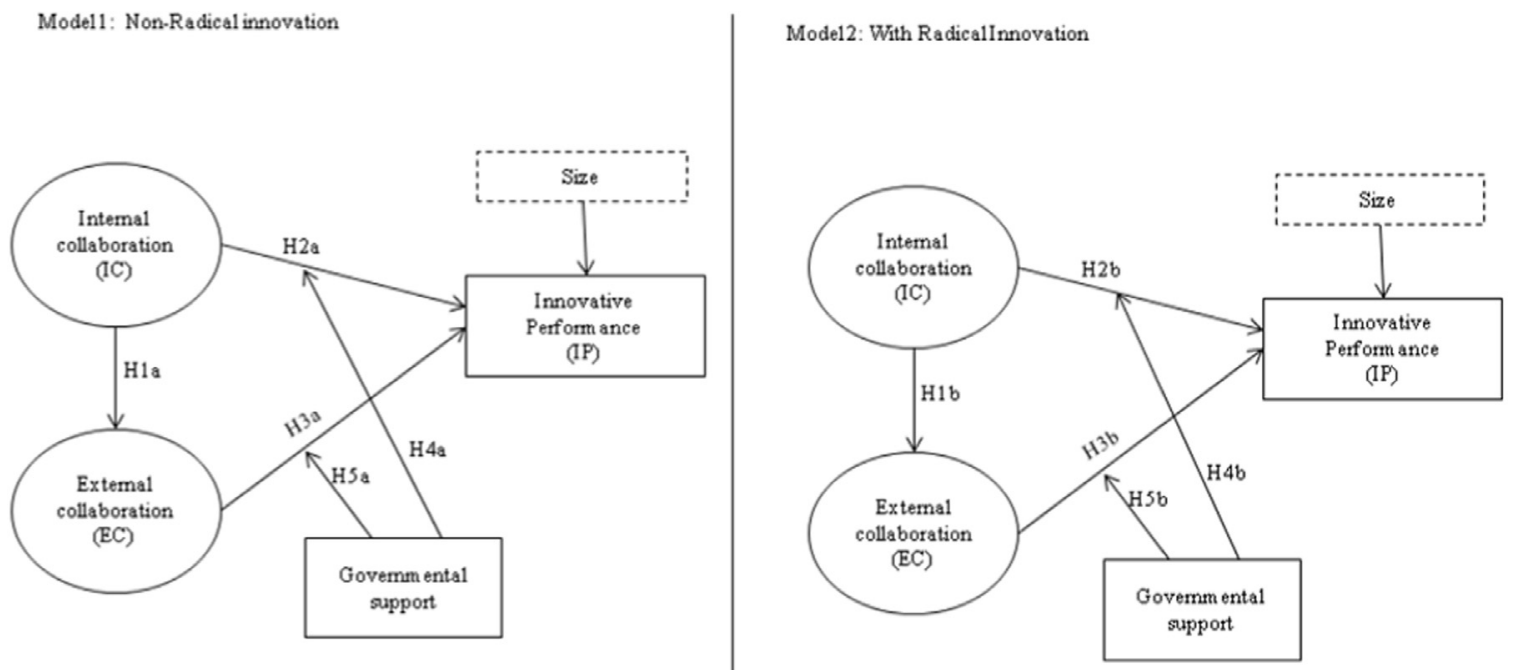

Fig. 1. Models tested in this research. 
Likert scale ranging between 1 (totally disagree) and 7 (totally agree). Radical innovation activities were measured on a 2-point scale: does the company have radical innovation activities (yes or no)? Based on the works of Bessant et al. (2014) and Oslo Manual (OECD, 2005), for the purposes of the questionnaire, radical innovation was explained as the creation of something completely new in terms of products, processes, materials or technologies.

\subsubsection{Measurement of control variables}

Firm size was measured with respect to four separate categories: micro-, small-, medium- and large-sized companies. This variable was included because, according to Josefy et al. (2015), this is one of the most relevant when planning and conducting managerial research. We used the Brazilian classification of firm size, which is based on the number of company employees (Sebrae, 2013). Micro-sized firms have a maximum of 19 employees, small-sized firms have between 20 and 99 employees, medium-sized firms have between 100 and 499 employees, and large-sized firms 500 or more employees. Government support for innovation was selected because of the previous results in this field of knowledge, which indicated that such support tends to play a positive role in promoting firms' innovative performance (Leyden et al., 1989; Kang and Park, 2012). The variable of government support for innovation activities was measured on a 2-point scale: has the company previously received or is receiving government support for innovation (yes or no)? All the research constructs were reflective. The list of studied variables and their respective codes is included in Appendix 1. The original questionnaire was developed and administered in Portuguese, although the appendix includes an English translation.

\subsection{Sampling and data collection procedures}

To identify the population of the companies to be surveyed, the databases of the Brazilian Association of Electrical and Electronic Industry (primarily known by its acronym in Portuguese: ABINEE) and the American Chamber of Commerce of Brazil (primarily known by its acronym in Portuguese: AMCHAM) were consulted. These associations were chosen because they have a large, concentrated number of firms from different economic sectors in Brazil that are considered technologically dynamic (IBGE, 2013), such as the electronics, industrial automation, automotive and telecommunications sectors. The survey included a cover letter, which discussed the informant's roles as the key respondent in their respective firms.

To manage the administration of the questionnaires, a website was created to host the research tool. It was possible to register the population of companies using this website and to send the link containing the questionnaire to each company. One hundred and twenty-four questionnaires were returned; eight were discarded because their response patterns were different from the remainder of the sample or because they had not been completed. Therefore, 116 questionnaires were obtained and were considered valid for the purposes of this survey. This quantity previously met the minimum sample size recommended in PLS-SEM in running multigroup analyses (PLS-MGA). To run PLS-MGA, the number of responses for each subgroup should equal or comparable to the sample size recommendations for a statistical power of $80 \%$. In this study, the minimum number of samples for each group must be equal to or greater than 52 with a significance level of $5 \%$ and R-square $=0.25$ (see Hair et al., 2017; Matthews, 2017).

The profile of the sample of respondent companies is as follows: $31.03 \%$ are micro-companies, $29.31 \%$ are small businesses, $27.59 \%$ are medium companies and $12.07 \%$ are large companies. Most of the respondents (86.21\%) occupy the following positions in their firms: directors, managers, owners, analysts, engineers and supervisors. Our final sample was categorized as follows: electronics (34 firms, 29.3\%); industrial automation (28 firms, 15.9\%); information technology (14 firms, 12.1\%); automotive (8 firms, 6.9\%); medical and hospital equipment (7 firms, 6\%); energy, oil and gas (6 firms, 5.2\%); and companies from other sectors, such as chemicals, telecommunications and agricultural machinery (21 firms, 18.1\%). No respondents reported any difficulty in understanding the meaning of the main research concepts, such as open innovation and radical innovation.

\subsection{Data analysis}

To analyze the data, a multigroup approach was adopted through PLS-MGA. This kind of analysis allows one to test whether pre-defined data groups have significant differences in their group-specific parameter estimates (e.g., outer weights, outer loadings and path coefficients), in this case of firms focusing on incremental innovation and radical innovation. Before running the PLS-MGA testing, we must first create test measurement models. The objective of this process is to ensure that the items forming the constructs used in the research are currently valid and reliable. Before running the PLS-MGA, we consider it to test the measurement invariance of composite models (MICOM) using a permutation procedure. We test the measurement invariance to ensure that the specific-group difference of the estimation model does not affect the results for the latent variables in the whole group (Henseler et al., 2016; Latan et al., 2017). From the analysis, it can be concluded that there is no difference variance and average values for both groups (see Table 5), which means there is no invariance problem that will affect the outcome. PLS-MGA testing was performed with the help of the SmartPLS 3 program (Ringle et al., 2015).

The main procedures used in the analysis adopted here were the following. The first was the partial least squares multigroup analysis (PLS-MGA), a non-parametric significance test for the difference of group-specific results that builds on PLS-SEM bootstrapping results. A result is significant at the $95 \%$ bias-corrected and accelerated (BCA) confidence interval for a certain difference of group-specific path coefficients. It should be noted, however, that the PLS-MGA method (Henseler et al., 2009), as implemented in SmartPLS, is an extension of Henseler's original nonparametric MGA method (as described, for example, by Sarstedt et al., 2011). The other procedure used was the permutation test, a non-parametric significance test for the difference in group-specific PLS-SEM results that assumes equal variances across groups.

\section{Research results}

According to Table 1 , composite reliability values of $0.60-0.70$ are acceptable in exploratory research, while in more advanced stages of research, values of between 0.70 and 0.90 can be regarded as satisfactory. Furthermore, for the standardization of outer loading, the value must be greater than 0.70 (although a value of 0.60 remains acceptable), and AVE values must be at least equal to 0.50 or higher,

Table 1

Final results convergent validity and internal consistency reliability (Full Sample, $\mathrm{n}=116)$.

\begin{tabular}{llllll}
\hline Latent variables & $\begin{array}{l}\text { Items/ } \\
\text { Indicators }\end{array}$ & $\begin{array}{l}\text { Outer } \\
\text { loadings }\end{array}$ & P-Value & AVE & rho_A \\
\hline Internal collaboration & IC1 & 0.831 & 0.000 & & \\
$\quad$ (IC) & IC2 & 0.765 & 0.000 & 0.656 & 0.737 \\
& IC3 & 0.832 & 0.000 & & \\
External & EC1 & 0.729 & 0.000 & & \\
collaboration & EC2 & 0.674 & 0.000 & & \\
(EC) & EC3 & 0.763 & 0.000 & 0.516 & 0.775 \\
& EC5 & 0.716 & 0.000 & & \\
Innovative & EC6 & 0.707 & 0.000 & & \\
performance (IP) & IP1 & 0.758 & 0.000 & & \\
& IP2 & 0.903 & 0.000 & 0.720 & 0.833 \\
& IP3 & 0.877 & 0.000 & & \\
\hline
\end{tabular}

Note: Items with outer loadings $<0.6$ have been excluded from the analysis (such as EC4 and EC7). 
Table 2

Correlations and discriminant validity Results (Full sample, $N=116$ ).

\begin{tabular}{llllll}
\hline $\begin{array}{l}\text { Latent } \\
\text { variables }\end{array}$ & Mean & S.D & $\begin{array}{l}\text { External } \\
\text { collaboration }\end{array}$ & $\begin{array}{l}\text { Innovative } \\
\text { performace }\end{array}$ & $\begin{array}{l}\text { Internal } \\
\text { Collaboration }\end{array}$ \\
\hline $\begin{array}{c}\text { External } \\
\quad \text { Collaborati- } \\
\text { on (EC) }\end{array}$ & 3.38 & 1.88 & $\mathbf{( 0 . 7 1 8 )}$ & 0.548 & 0.630 \\
$\begin{array}{c}\text { Innovative } \\
\text { Performace } \\
\text { (IP) }\end{array}$ & 4.92 & 1.69 & $0.479^{*}$ & $\mathbf{( 0 . 8 4 9 )}$ & 0.747 \\
$\begin{array}{c}\text { Internal } \\
\text { Collaborati- } \\
\text { on (IC) }\end{array}$ & 4.29 & 1.99 & $0.488^{*}$ & $0.590^{*}$ & $\mathbf{( 0 . 8 1 0 )}$ \\
\hline
\end{tabular}

Note: *Correlation is significant at the 0.05 level (2-tailed).

Square roots of average variances extracted (AVEs) shown on diagonal must be higher than correlations.

Above the diagonal elements are the HTMT values.

which indicates that, on average, the construct explains more than half of the variance of its indicators (Hair et al., 2017; Latan et al., 2016). From the results, it can be observed that the constructs IC, EC and IP have convergent validity and that internal consistency reliability (rho_A) was very good for the outer reflective models.

The Fornell-Larcker criterion is a first and more conservative approach to assessing discriminant validity. This criterion compares the square root of the AVE values with the latent variable correlations. Specifically, the square root of each construct's AVE should be greater than its highest correlation with any other construct. Within this method, the value of the root squared AVE will provide the maximum shared squared variances (MSV) or the average shared squared variances (ASV). The logic of this method is based on the idea that a construct shares more variance with its associated indicators than with any other construct (Latan and Ghozali, 2015; Latan and Noonan, 2017). The results show that the model has good discriminant validity (Table 2).

In accordance with the values shown in Table 2, we followed guidelines taken from Nunnally and Bernstein (1994), who distinguish between four types of correlations, two of which are relevant for discriminant validity assessment. First, the monotrait-heteromethod correlations quantify the relationships between two measurements of the same construct by means of different methods (i.e., items). Second, the heterotrait-heteromethod correlations quantify the relationships between two measurements of different constructs by means of different methods. In essence, as Nunnally and Bernstein suggest (1994), the HTMT approach is an estimate of the correlation between the constructs that parallel the disattenuated construct score correlation. Technically, the HTMT approach provides two advantages over the disattenuated construct score correlation: it does not require a factor analysis to obtain factor loadings, and it does not require the calculation of construct scores. Of the three approaches, HTMT $_{.85}$ is the most conservative criterion, while HTMT .90 and HTMT ${ }_{.95}$ indicate that discriminant validity has been established (Henseler et al., 2015). The results show that the model has good discriminant validity (HTMT values $<.90$ ). The results of this HTMT are similar to the Fornell-Larcker criterion noted above.

Tables 3, 4 show values for both Sample A (non-radical innovation- based firms) and Sample B (radical innovation-based firms).

Both models (Sample A, non-radical; Sample B, radical) have a value of R-square and adjusted R-square that can be considered satisfactory; the $\mathrm{Q}$ predictive validity was also considered sufficient. This finding means that the predictors in the models are able to explain the variance in the dependent variable. The resulting effect, the size value of each predictor, is also very good, with internal collaboration (IC) variables having the greatest contribution, equal to 0.426 for non-radical innovation and 0.288 for the radical innovation model. The VIF value generated for all predictors is $<3.3$, which means that there is no problem collinearity among the independent variables for either group model. For the goodness of fit model, for the PLS, we can observe two categories: the standardized root mean squared residual (SRMR) and the normed fix index (NFI). It is recommended that the SRMR value be equal to or less than 0.08 (Hu and Bentler, 1998), while the NFI value must be greater than 0.90 (Hair et al., 2017). From the analysis, it can be concluded that Model A (non-radical) has a good fit, with an SRMR value of 0.098 and a relative NFI value of 0.814 . Although the SRMR and NFI values were slightly larger than recommended, the value remains acceptable. Hair et al. (2017, p. 193) state that, when using PLS-SEM, it is important to recognize that the term 'fit' has different meanings in the context of CB-SEM and PLS-SEM respectively. Thus, the threshold is likely to be excessively low for PLS-SEM. This finding is because the discrepancy between the observed correlations and the model-implied correlations plays a different role in CB-SEM than in PLS-SEM. According to Latan and Noonan (2017), an SRMR value above 0.10 can be insufficient, as Model B (radical) has a poorer fit.

To test whether there is common method bias, the value of the average full collinearity VIF is assessed. Common method bias, often called common method variance (CMV), is one of the most important issues to have been discussed in social science research in the last three decades. This bias generally results from variants of the same methods influencing the correlation between variables that were measured by the same method. This problem is often associated with its own reporting techniques (self-reports) on the data collection questionnaire and potential measurement error. Some researchers suggest controlling for this bias to avoid inflation (increase) resulting in strong relations between the constructs (or supporting the theory, an increase in Type I errors) and deflation (decrease) resulting in a relationship between the constructs becoming weak (or rejecting the theory, increasing Type II error). The recommended AFVIF value is $<3.3$ (Kock, 2015), indicating no problem with CMV. From the analysis, it can be concluded that there is no problem with CMV, as the AFVIF value generated for the non-radical is 1.513 , and that for the radical is 1.309 .

Hypothesis testing is conducted by using a bootstrapping approach for 2000 subsamples and using a significance level of $5 \%$ one-tails. The analysis showed that H1a, H2a and H3a are acceptable to the sample non-radical group, which generated significant value from $95 \%$ biascorrected and accelerated $(\mathrm{BCa})<0.01$, respectively. Similarly, H1b, $\mathrm{H} 2 \mathrm{~b}$ and H3b are also acceptable for the sample group for radical innovation, which generated a significant value from $95 \%$ bias-corrected and accelerated $(\mathrm{BCa})<0.01$, respectively. If viewed from the fit model, a sample of the non-radical group has a better fit than the nonradical group sample.

Figs. 2 and 3 show the outer and inner models for Sample A. Figs. 4

Table 3

Structural model results (Sample A: Incremental Innovation).

\begin{tabular}{|c|c|c|c|c|c|c|c|c|}
\hline Latent variables & $\begin{array}{l}\text { R-Squared } \\
\left(R^{2}\right)\end{array}$ & Adj. $R^{2}$ & $\begin{array}{l}\text { Effect size } \\
\left(\mathbf{f}^{2}\right)\end{array}$ & $\mathbf{Q}^{2}$ & VIF & AVIF & SRMR & NFI \\
\hline Internal Collaboration (IC) & - & - & 0.426 & - & 1.415 & - & - & - \\
\hline External Collaboration (EC) & 0.260 & 0.248 & 0.085 & 0.248 & 1.484 & - & - & - \\
\hline Innovative Performance (IP) & .508 & 0.474 & - & 0.476 & - & 1.513 & 0.098 & 0.814 \\
\hline Governmental Support (GS) & - & - & 0.000 & - & 1.192 & - & - & - \\
\hline Size & - & - & 0.005 & - & 1.050 & - & - & - \\
\hline
\end{tabular}


Table 4

Structural model results (Sample B: Radical Innovation).

\begin{tabular}{|c|c|c|c|c|c|c|c|c|}
\hline Latent variables & $\begin{array}{l}\text { R-Squared } \\
\left(\mathbf{R}^{2}\right)\end{array}$ & Adj. $\mathbf{R}^{2}$ & $\begin{array}{l}\text { Effect size } \\
\left(f^{2}\right)\end{array}$ & $Q^{2}$ & VIF & AFVIF & SRMR & NFI \\
\hline Internal Collaboration (IC) & - & - & 0.288 & - & 1.325 & - & - & - \\
\hline External Collaboration (EC) & 0.223 & 0.208 & 0.121 & 0.208 & 1.425 & - & - & - \\
\hline Innovative Performance (IP) & .322 & 0.266 & - & 0.271 & - & 1.309 & 0.116 & 0.623 \\
\hline Governmental Support (GS) & - & - & 0.024 & - & 1.116 & - & - & - \\
\hline Size & - & - & 0.000 & - & 1.127 & - & - & - \\
\hline
\end{tabular}

and 5 show the outer and inner models for Sample B. Differences between Samples A and B may be found, mainly in terms of the role of control variables.

Table 5 presents the results of the tested hypothesis for the relationships among variables, confirming their acceptance.

To determine whether there are differences between the two groups (non-radical and radical), the researchers ran a multigroup analysis. The sample was divided into two groups, totaling 63 for the first sample, while the second sample totaled 53. Multigroup analysis was conducted using two approaches, non-parametric PLS-MGA and a permutation test. Both approaches were chosen because they do not require the assumption that such data should be normal and do not require the group to have the same variance (Matthews, 2017). The analysis showed that there was no difference between the two groups viewed from every path coefficient. This finding shows that there is no difference between samples with non-radical innovation and radical innovation. Consequently, the entire proposed hypothesis can be considered accepted for both Sample A and Sample B.

We examine the role of the GS in the relationship between variables in two samples using the orthogonalizing approach. This approach was chosen because it produces an accurate estimate, has a high predictive accuracy and is able to minimize the collinearity problem. The results of the analysis of interactions are given in Table 6.

Table 6 shows that H4a, H4b, H5a and H5b are fully supported, where government support (GS) may moderate the effect of the relationship between IC and EC on IP. From the analysis results, the value of coefficient $(\beta)$ to the relationship IC $\mathrm{x}$ GS $\rightarrow$ IP obtained for each group was 0.152 and 0.292 with $95 \%$ bias-corrected and accelerated (BCa) $<0.05$. Furthermore, the value of the coefficient $(\beta)$ on the relationship EC x GS $\rightarrow$ EMT is 0.158 and 0.310 with $95 \%$ bias-corrected and accelerated $(\mathrm{BCa})<0.05$, respectively.

\section{Discussion}

Based on the research results and the main arguments taken from the literature, some lines of discussion emerge. Generally, the proposed research model based on five research hypotheses can be considered relevant in explaining the reality of both Sample A and Sample B. Consequently, and regardless of the type of innovation (non-radical or radical), internal collaboration tends to influence external collaboration positively, confirming some previous views (Chiaroni et al., 2011; Love et al., 2011; Salter et al., 2014a). On the other hand, both internal collaboration and external collaboration positively influence innovative performance in the Brazilian sample analyzed here. These findings are in agreement with Laursen and Salter (2006), Huizingh (2011), Greco et al. (2015) and Ritala et al. (2015). However, unlike the study conducted by Ritala et al. (2015), our research did not investigate the leaking of knowledge by a firm's employees in external collaboration efforts.

When considering the specific results for Sample A and Sample B, some interesting conclusions appear. First, in Sample A, which is focused on firms with non-radical innovation, IC tends to explain EC more clearly than in Sample B, which is focused on radical innovation firms. This finding confirms that, as Cheng and Shiu (2015) suggest, IC tends to be more relevant as an organizational antecedent than EC in contexts of incremental innovation, mainly because internal knowledge is acknowledged as a key resource driving innovative efforts in companies (Forés and Camisón, 2016). In Sample A, IC and EC constructs together explained IP more powerfully than the data observed in Sample B.

Firm size was considered more relevant in the case of Sample A than of Sample B. This finding implies that the larger a firm is, the lower its degree of radical innovativeness and vice versa. This result is in accordance with Fóres and Camissón's argument (2015) that non-radical innovation tends to be more sensitive to firm size than radical innovation is. This kind of size effect also confirms the key role played by firm size as an organizational variable that should be considered when extending managerial theory (Josefy et al., 2015).

In considering the existence of government support for innovation, our hypotheses are largely supported. The first insight is the importance of government support for innovation performance. Most interestingly, the analysis reveals its importance in shaping internal and external collaboration. Government support and external collaboration are positively associated with innovative performance, presumably because this reduces the so-called network failures in innovation activities. This finding means that it is necessary to allow the right network of internal and external actors to meet for radical innovation to occur. Another possible reason is that governments usually support the riskiest research, whether applied or basic, and indeed such support has often been the source of the most radical, path-breaking types of innovation, not only creating the conditions for radical innovation, but also fostering internal and external collaboration to allow the commercial development to occur.

We found less robust support for innovative performance in government support and internal/external collaboration in the case of Sample A, and government support and internal collaboration with Sample B. Government support and internal/external collaboration are

Table 5

PLS-MGA results (Direct Effect).

\begin{tabular}{|c|c|c|c|c|c|c|c|c|}
\hline Relationships & Non-Radical & Radical & Differ & PLS-MGA & $\begin{array}{l}\text { 95\% BCA CI } \\
\text { Permutation }\end{array}$ & MICOM & Equal Variances & Decision \\
\hline IC $\rightarrow$ EC & $0.510^{\text {k*k }}$ & $0.473^{\text {** }}$ & 0.038 & $0.388^{\text {n.s }}$ & $0.216^{\mathrm{n} . \mathrm{s}}$ & $(-0.399 ;-0.232)^{\mathrm{n} . \mathrm{s}}$ & Yes & H1 Supported \\
\hline $\mathrm{IC} \rightarrow \mathrm{IP}$ & $.545^{* \star}$ & $0.340^{\text {** }}$ & 0.205 & $0.090^{\text {n.s }}$ & $0.272^{\mathrm{n} . \mathrm{s}}$ & $(-0.399 ;-0.661)^{\mathrm{n} . \mathrm{s}}$ & Yes & H2 Supported \\
\hline $\mathrm{EC} \rightarrow \mathrm{IP}$ & $.250^{\text {** }}$ & $0.341^{\text {*** }}$ & 0.092 & $0.706^{\mathrm{n} . \mathrm{s}}$ & $0.279^{\text {n.s }}$ & $(-0.232 ;-0.661)^{\mathrm{n} . \mathrm{s}}$ & Yes & H3 Supported \\
\hline
\end{tabular}

n.s., not significant.

${ }^{*} \mathrm{p}<0.05$ (one-tailed test).

${ }^{* *} \mathrm{p}<0.01$ (one-tailed test). 


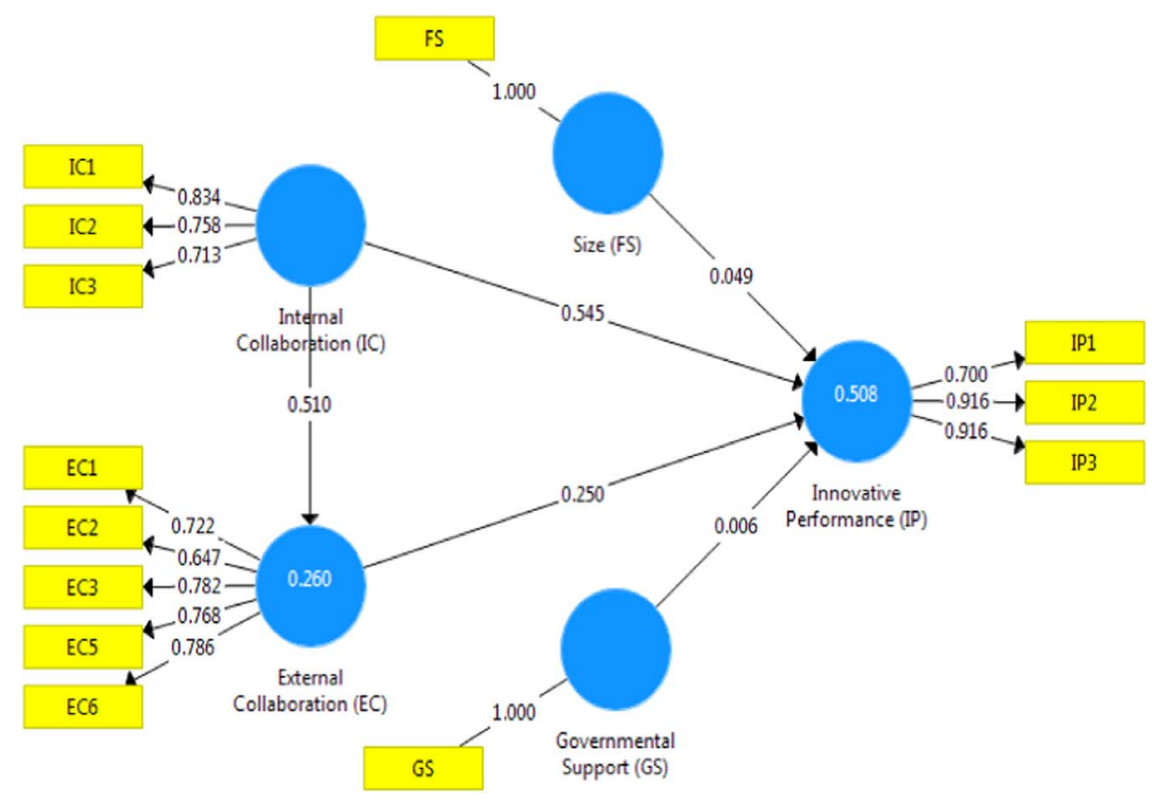

Fig. 2. Outer Model - Sample A (Non-Radical Innovation).

positively associated with innovative performance in the case of Sample A, though to a lower extent than with external collaboration with Sample B. Does this mean that government support is less important in shaping internal and external collaboration in Sample A (incremental innovation)? This result may indicate whether Brazilian firms that receive government support are likely to pursue radical innovation. This evidence is in agreement with Leyden et al. (1989)'s study of the positive role of government in promoting more innovation-related knowledge among innovative firms. More recently, Kang and Park (2012) have suggested that government support affects firms' innovation by stimulating their main R\&D activities.

Certain differences and similarities were found when comparing the constructs of Models A and B, as follows:

- In Sample A, in construct IC, the most relevant item was IC1. This finding may suggest that a better use of employees' knowledge can boost the incremental innovative process, as suggested by Cheng and Shiu (2015) and Fóres and Camissón (2015). As Reagans and Zuckerman (2008) argue, the redundant ties lead most organizations to focus on knowledge exploitation. On the other hand, in Sample B, IC3 was more relevant, confirming that radical innovation should embrace a proper organizational architecture, which should have a set of pro-innovation mechanisms (Salter et al., 2014b).

- In Sample A, construct EC, the most relevant item was EC6, but in Sample B, it was EC1. This difference can be explained because less innovative firms do not generally have a proper R\&D department or other laboratories necessary for boosting innovation. In this context, these firms tend to rely on external R\&D structures, suggesting a triple helix-inspired perspective (Leydesdorff and Etzkowitz, 1998; Etzkowitz et al., 2005). On the other hand, larger companies tend to

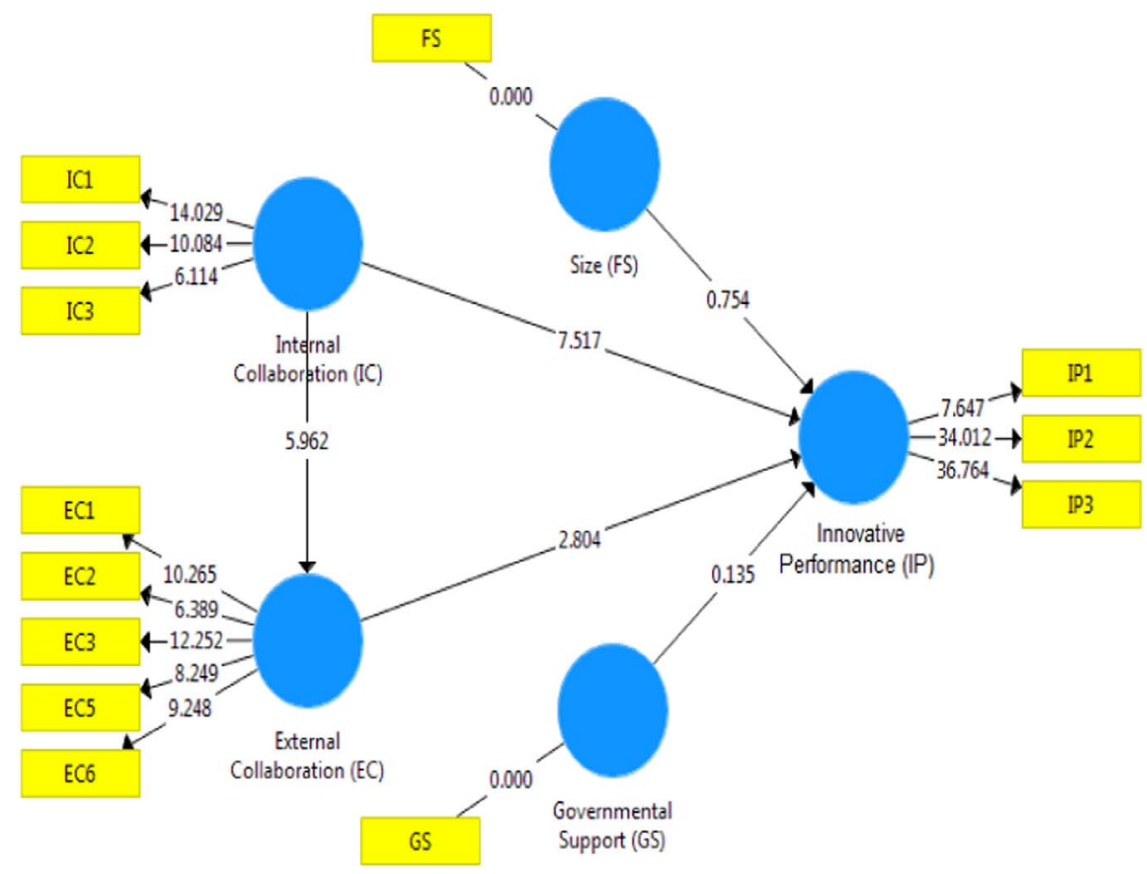

Fig. 3. Inner Model - Sample A (Non-Radical Innovation). 


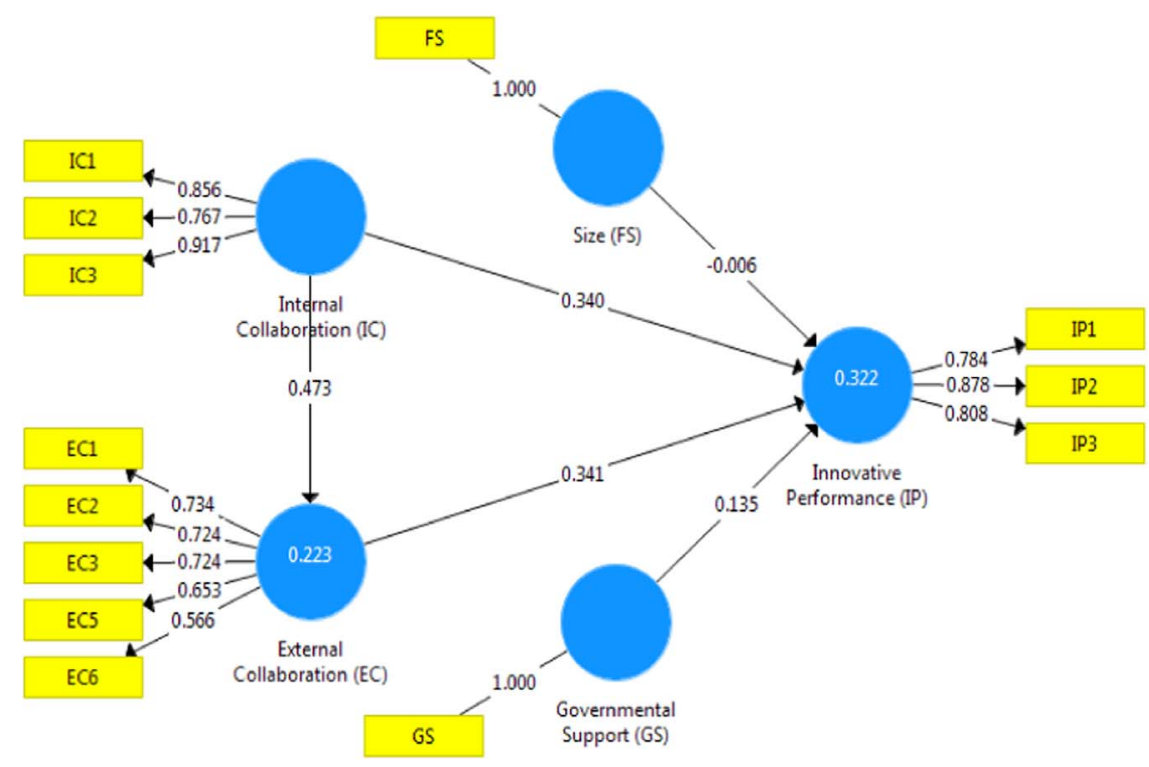

Fig. 4. Outer Model - Sample B (With Radical Innovation).

have their own resources with which to establish a proper R\&D department and other laboratories (Van de Vrande et al., 2009). Of course, this kind of result should be explored further in future studies.

- Regarding the IP construct, for both Samples A and B, IP2 assumed the position of the most relevant item. This finding indicates that innovation performance is intimately related to the development or application of new technologies and production processes. It also highlights the relevance of creating a suitable organizational architecture for embracing innovation (Salter et al., 2014b).

The similarities and differences between Samples A and B noted above show that the level of innovation plasticized by the companies in this study matters, affecting the power of the relationships between constructs. The results also highlight the role of GS in promoting innovation in firms in emerging economies such as Brazil's.

Further analyses of the EC construct allow the identification of "competitiors" and "consultants" as aspects with insufficient relevance to remain within Models A and B. One possible reason for this finding is the generally weak collaboration among firms and such stakeholders.
Table 6

Relationships between variables (Interaction Effect).

\begin{tabular}{lllll}
\hline Structural path & Coef $(\boldsymbol{\beta})$ & S.D & 95\% BCa CI & Conclusion \\
\hline IC x GS $\rightarrow$ IP (Incremental) & 0.152 & 0.096 & $(0.307,0.019)^{*}$ & H4a Supported \\
EC x GS $\rightarrow$ IP & 0.158 & 0.104 & $(0.340,0.022)^{*}$ & H5a Supported \\
$\quad$ Incremental) & & & & \\
IC x GS $\rightarrow$ IP (Radical) & 0.292 & 0.130 & $(0.124,0.012)^{*}$ & H4b Supported \\
EC x GS $\rightarrow$ IP (Radical) & 0.310 & 0.115 & $(0.499,0.003)^{* *}$ & H5b Supported \\
\hline
\end{tabular}

Note: **, * statistically significant at the 1 percent and 5 percent levels, respectively.

Future studies may develop further insights and provide a better understanding of this phenomenon.

There was also an expectation that companies conducting radical innovation activities would be those with greater innovative performance, but this expectation was not confirmed, suggesting that radical innovation strategy may be riskier over the short term. This result is consistent with observations made by Shane and Ulrich (2004) and Hauser et al. (2006) that companies that are more ambitious in terms of

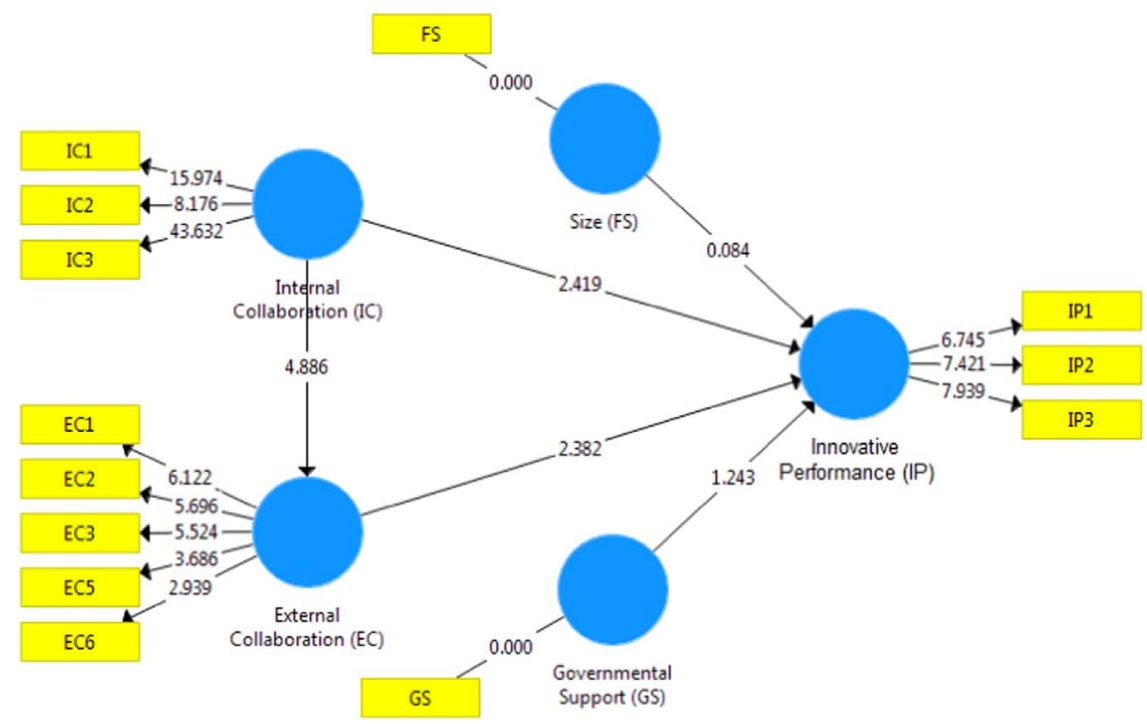

Fig. 5. Inner Model - Sample B (With Radical Innovation). 
innovation were often disappointed in terms of sales and total return rates.

\subsection{Theoretical implications}

It is widely understood that radical and incremental innovation efforts require different management practices, capabilities and organizational components (Bessant et al., 2010). As a result, there are many gaps in the literature concerning OI and its impact on incremental and radical innovation performance (Cheng and Shiu, 2015; Greco et al., 2015). Firms that introduce radical innovations rely more on external linkages, while those that have incremental innovations rely more on internal linkages. Specifically, one lesser known aspect is related to the boundaries of collaboration and their influence on radical and incremental innovation. To date, no studies have approached the understanding of government support and its moderating role in the relationship between organizational boundary collaboration and innovation performance. In this manner, our study takes the opportunity to fill this gap in knowledge and to open up possibilities for further investigative studies. We offer several contributions to the scholarship on OI and their influence on radical and incremental innovation.

The majority of the OI literature has directed its attention toward understanding the consequences and effective management of OI in the context of the developed world. Few studies have been published on this topic in firms operating in developing countries. In contrast, our study represents a first attempt to fill this gap and to examine empirically the moderating role that government support plays in the OI approach, based on original data from firms operating in Brazil. Additionally, from the methodological point of view, this research originally tested different models of samples with different levels of radicalism in innovation.

In so doing, the study addresses a recent development in the OI literature, where a very small but growing body of investigations seeks to understand the elusive nature of boundary collaborations and their influence on radical and incremental innovation. Our results provide evidence that IC tends to be more relevant as an organizational antecedent than EC in contexts of incremental innovation. They also offer valuable preliminary insights about the importance of government support in shaping internal and external collaboration. While government support and a network of external actors may benefit radical innovation, it may not be conducive to arriving at a shared interpretation. Future research will need to investigate these effects further.

\subsection{Implications for practice}

While the claims regarding collaboration effects in innovation are hardly contentious, it is not clear whether the management of collaboration practices associated with incremental innovations is similarly applicable to radical innovations. The possibility that internal and external collaboration can be shaped to increase desired outcomes in incremental and radical innovation outcomes has neither been articulated nor examined. Our results indicate that simply focusing on increasing internal and external collaboration cannot be relied upon to generate the desired results.

What is more, government support has a strong impact on shaping both internal and external collaboration, thus creating the conditions for radical innovation. This indicates that project managers must think beyond the firm's resources to embrace government support in order to foster radical innovations. Rather, to improve the performance of radical and incremental innovation projects, practitioners must also consider how to overcome internal organizational and cultural barriers related to innovation and how to coordinate and steer interactions among internal and external members, who contribute such technical skills and expertise. To capitalize on OI to create the conditions for radical innovation, managers should initially foster external collaborations to staff a radical innovation project, searching for government support. Later, as the project progress, team interaction could benefit from an increasing number of external members.

\subsection{Implications for policy}

Our findings have important policy implications. They may inform policy-makers on the different roles that state support can play in boosting innovation, whether radical or incremental. First, state support has a clear effect on innovation. Based on our empirical findings, we expect that better policy strategies can be developed wisely capable of supporting the diffusion and recombination of existing and diverse scientific and technological knowledge bases. While our study focuses on firms that belong to innovative sectors in Brazil, there are clearly implications for understanding how new industrial policies are likely to affect the different types of innovation. Our analysis suggests the importance of policy-makers actually establishing a mechanism to encourage companies to innovate and that this support is not only financial. As the study by Cano-Kollmann et al. (2017) shows, nonmonetary support (e.g., facilitating networking and coordinating collaboration) may be more effective in enabling OI and improving industrial competitiveness. Policy-makers may find interesting the positive impact of state policies on how firms cooperate and co-create within an industry, and the importance of financial and non-monetary support from the state in improving innovative performance among firms. This may be used to predict better ways of prioritizing investments to ensure long-term economic growth.

Also, the present research indicates the importance of further stimulating external collaborative efforts between the heterogeneous actors involved in order to leverage innovative dynamics, ensuring that different economic actors can recombine their knowledge bases more effectively. For firms in emerging economies, the existence of policies that support the diffusion of knowledge is fundamental in maintaining radical innovation. These policies are more likely to reduce the possibility of the 'rentiership' of innovation, in which the creation of value is dependent on secret knowledge, thus limiting the possibilities to OI.

\section{Conclusion}

The main objective of the research described here was to test five research hypotheses regarding the relationships between OI, innovative performance, the role of government support and firms' size in this process. All the suggested hypotheses were indeed confirmed, showing that IC influences EC and that they are both related to a superior IP. This research also provided fresh knowledge about these relationships in two different contexts, one more oriented to non-radical innovation, the other oriented to firms pursuing radical innovation. We believe that the main research contributions emerge from this particular comparison, where there are some interesting findings. For example, it was discovered that government support plays a key role in boosting firms pursuing radical innovation.

Highlighting certain research limitations, we recognize that there is a clear sample limitation, as the research was based on Brazilian firms alone. Another limitation is that data were collected directly from each firm's respondents, carrying with it a risk of bias. The choice of certain constructs also represents a limitation of the article. Future studies could include other control variables related to firm characteristics (e.g., internal R\&D activities that may also contribute to the success of innovation projects). In addition, future OI research could use other variables to investigate innovative performance (e.g., the share of turnover from radical or incremental innovations). Future studies could deepen further the analysis of relationships between government support, OI and innovative performance.

Finally, some findings emerged for which we were not able to provide a comprehensive explanation. For example, companies with radical innovation activities were expected to show better indicators in terms of innovative performance; this was not verified. These results 
warrant further and deeper study using a case-study perspective that might explain why this effect occurs. Furthermore, we believe that construct items, such as EC4 and EC7, deserve further research efforts to provide a clearer picture of the role they play in the innovative performance of firms.

\section{Appendix 1. - Studied variables}

\begin{tabular}{lll}
\hline Construct & Code & Items \\
\hline EC & EC1 & Suppliers \\
& EC2 & Customers \\
EC3 & Universities \\
EC4 & Competitors \\
EC5 & Government \\
& EC6 & Research institutes \\
& EC7 & Consultants \\
& IC1 & The employees at my company usually have opinions about improving products, processes, services, or sales and \\
& & distribution. \\
IC & IC2 & Cross-functional teams have been formed with representatives from engineering, R\&D, marketing, and production, for \\
& IC3 & My comple, for the integrated development of innovations. \\
& IP 1 & The company has developed a higher number and variety of products and/or services. \\
IP & IP2 & The company has developed and/or applied new technologies in production and/or services. \\
& IP 3 & The company has developed and/or applied new ways to organize and manage work. \\
C1 & What is the company's size? \\
Control & variables & Has the company already received or is it currently receiving government support for innovation? \\
\hline
\end{tabular}

\section{References}

Bessant, J., Öberg, C., Trifilova, A., 2014. Framing problems in radical innovation. RD Manag. 43, 1284-1292.

Bessant, J., Von Stamm, B., Moeslein, K.M., Neyer, A.K., 2010. Backing outsiders: selection strategies for discontinuous innovation. RD Manag. 40, 345-356.

Baregheh, A., Rowley, J., Sambrook, S., 2009. Towards a multidisciplinary definition of innovation. Manag. Decis. 47, 1323-1339.

Bogers, M., Zobel, A.K., Afuah, A., Almirall, E., Brunswicker, S., Dahlander, L., Frederiksen, L., Gawer, A., Gruber, M., Haefliger, S., Hagedoorn, J., Hilgers, D., Laursen, K., Magnusson, M.G., Majchrzak, A., McCarthy, I.P., Moeslein, K.M., Nambisan, S., Piller, F.T., Radziwon, A., Rossi-Lamastra, C., Wal, A.L.J.T., 2017. The open innovation research landscape: established perspectives and emerging themes across different levels of analysis. Ind. Innov. 24, 8-40.

Breunig, K.J., Aas, T.H., Hydle, K.M., 2014. Incentives and performance measures for open innovation practices. Meas. Bus. Excell. 18, 45-54.

Burcharth, A.L.A., Knudsen, M.P., Søndergaard, H.A., 2014. Neither invented nor shared here: the impact and management of attitudes for the adoption of open innovation practices. Technovation 34, 149-161.

Büschgens, T., Bausch, A., Balkin, D.B., 2013. Organizing for radical innovation - a multilevel behavioural approach. J. High Technol. Manag. Res. 24, 138-152.

Caloffi, A., Rossi, F., Russo, M., 2015. What makes SMES more likely to collaborate? Analyzing the role of regional innovation Policy. Eur. Plan. Stud. 23, 1245-1264.

Cano-Kollmann, M., Hamilton, R., D., Mudambi, R., 2017. Public support for innovation and the openness of firms' innovation activities. Ind. Corp. Change 26 (3), 421-442.

Chang, Y., Chang, H., Chi, H., Chen, M., Deng, L., 2012. How do established firms improve radical innovation performance? The organizational capabilities view. Technovation 32, 441-451.

Chen, J., Chen, Y., Vanhaverbeke, W., 2011. The influence of scope, depth, and orientation of external technology sources on the innovative performance of Chinese firms. Technovation 31, 362-373.

Cheng, C.C.J., Huizingh, E.K.R.E., 2014. When is open innovation beneficial? The role of strategic orientation. J. Product. Innov. Manag. 31, 1235-1253.

Cheng, C.C.J., Shiu, E.C., 2015. The inconvenient truth of the relationship between open innovation activities and innovation performance. Manag. Decis. 53, 625-647.

Chesbrough, H., 2003a. Open Innovation. Harvard University Press, Cambridge, MA.

Chesbrough, H., 2003b. The era of open innovation. MIT Sloan Manag. Rev. 44, 35-41.

Chiang, Y.H., Hung, K.P., 2010. Exploring open search strategies and perceived innovation performance from the perspective of inter-organizational knowledge flows. RD Manag. 40, 292-299.

Chiaroni, D., Chiesa, V., Frattini, F., 2011. The Open Innovation journey: how firms dynamically implement the emerging innovation management paradigm. Technovation 31, 34-43.

Esteves, K., Feldmann, P.R., 2016. Why Brazil does not innovate: a comparison among nations. RAI Rev. De. Adm. e Inov. 13, 29-38.

Etzkowitz, H., Mello, J., Almeida, M., 2005. Towards 'meta-innovation' in Brazil: the evolution of the incubator and the emergence of a triple helix. Res. Policy 34, 411-424.
Fabiani, S., Sbragia, R., 2014. Tax incentives for technological business innovation in Brazil: the use of the Good law - Lei do Bem (law No. 11196/2005). J. Technol. Manag. Innov. 9, 53-63.

Forés, B., Camisón, C., 2016. Does incremental and radical innovation performance depend on different types of knowledge accumulation capabilities and organizational size? J. Bus. Res. 69, 832-848.

Garcia, R., Calantone, R., 2002. A critical look at technological innovation typology and innovativeness terminology: a literature review. J. Product. Innov. Manag. 19, $110-132$.

Gassmann, O., Enkel, E., Chesbrough, H., 2010. The future of open innovation. RD Manag. 40, 213-221.

Gobbo Júnior, J.A., Olsson, A., 2010. The transformation between exploration and exploitation applied to inventors of packaging innovations. Technovation 30, 322-331.

Goedhuys, M., Veugelers, R., 2012. Innovation strategies, process and product innovations and growth: firm-level evidence from Brazil. Struct. Change Econ. Dyn. 23, $516-529$.

Greco, M., Grimaldi, M., Cricelli, L., 2015. Open innovation actions and innovation performance: a literature review of European empirical evidence. Eur. J. Innov. Manag. 18 (1460-1060).

Griffin, A., Price, R.L., Vojak, B.A., Hoffman, N., 2014. Serial Innovators' processes: how they overcome barriers to creating radical innovations. Ind. Mark. Manag. 43, 1362-1371.

Hair, J.F., Hult, G.T.M., Ringle, C.M., Sarstedt, M., 2017. A Primer on Partial Least Squares Structural Equation Modeling (PLS-SEM), 2nd edn. Sage Publications, Thousand Oaks.

Hagedoom, J., Cloodt, M., 2003. Measuring innovative performance: is there an advantage in using multiple indicators? Res. Policy 32, 1365-1379.

Hauser, J., Tellis, G.J., Griffin, A., 2006. Research on innovation: a review and agenda for Marketing Science. Mark. Sci. 25, 687-717.

Henseler, J., Ringle, C.M., Sarstedt, M., 2015. A new criterion for assessing discriminant validity in variance-based structural equation modeling. J. Acad. Mark. Sci. 43, $115-135$.

Henseler, J., Ringle, C.M., Sarstedt, M., 2016. Testing measurement invariance of composites using partial least squares. Int. Mark. Rev. 33, 405-431.

Henseler, J., Ringle, C.M., Sinkovics, R.R., 2009. The use of partial least squares path modeling in international marketing. Adv. Int. Mark. 20, 277-319.

Holl, A., Rama, R., 2012. Technology sourcing: are biotechnology firms different? An exploratory study of the Spanish case. Sci. Public Policy 29, 304-317.

Hosseini, S., Kees, A., Manderscheid, M.R., Rosemann, M., 2017. What does it take to implement open innovation? Towards an integrated capability framework. Bus. Process Manag. J. 23, 87-107.

Hu, L.-T., Bentler, P.M., 1998. Cutoff criteria for fit indexes in covariance structure analysis: conventional criteria versus new alternatives. Struct. Equ. Model.: a Multidiscip. J. 6, 1-55.

Huizingh, K.R.E., 2011. Open innovation: state of the art and future perspectives. Technovation 31, 2-9.

Hung, K., Chou, C., 2013. The impact of open innovation on firm performance: the moderating effects of internal R\&D and environmental turbulence. Technovation 33, 368-380. 
IBGE, 2013. PINTEC - Technological National Survey, Rio de Janeiro, Brazil, 2013 (in Portuguese).

Inauen, M., Schenker-Wicki, A., 2015. Fostering radical innovations with open innovation. Eur. J. Innov. Manag. 15, 212-231.

Jones, J.M., Coppe, J., Kintz, A., 2016. Peering into the future of innovation management. Res.-Technol. Manag. 59, 49-58.

Josefy, M., Kuban, S., Ireland, R., Hitt, M., 2015. All things great and small: organizational size, boundaries of the firm, and a changing environment. Acad. Manag. Ann. 9.

Kang, K., Park, H., 2012. Influence of government R\&D support and inter-firm collaborations on innovation in Korean biotechnology SMEs. Technovation 32, 68-78.

Kim, B., Kim, E., Foos, N.J., 2016. Balancing absorptive capacity and inbound open innovation for sustained innovative performance: an attention-based view. Eur. Manag. J. 34, 80-90.

Kock, N., 2015. Common method bias in PLS-SEM: a full collinearity assessment approach. Int. J. e-Collab. 11, 1-10.

Knudsen, M.P., Mortensen, T.B., 2011. Some immediate-but negative-effects of openness on product development performance. Technovation 31, 54-64.

Krause, D.R., Pagell, M., Curkovic, S., 2001. Toward a measure of competitive priorities for purchasing. J. Oper. Manag. 19, 497-512.

Latan, H., Ghozali, I., 2015. Partial Least Squares: Concepts, Techniques and Application using program SmartPLS 3.0, 2nd edn. Diponegoro University Press, Semarang.

Latan, H., Jabbour, C.J.C., Jabbour, A.B.L., 2017. Ethical awareness, ethical judgment and whistleblowing: a moderated mediation analysis. J. Bus. Ethics. http://dx.doi. org/10.1007/s10551-017-3534-2.

Latan, H., Noonan, R. (Eds.), 2017. Partial Least Squares Path Modeling: Basic Concepts, Methodological Issues and Applications. Springer International Publishing, Cham.

Latan, H., Ringle, C.M., Jabbour, C.J.C., 2016. Whistleblowing intentions among public accountants in Indonesia: testing for the moderation effects. J. Bus. Ethics. http://dx. doi.org/10.1007/s10551-016-3318-0.

Laursen, K., Salter, A., 2006. Open for innovation: the role of openness in explaining innovation performance among U.K. manufacturing firms. Strategic Manag. J. 27, 131-150.

Laursen, K., Salter, A., 2014. The paradox of openness: appropriability, external search and collaboration. Res. Policy 43, 867-878.

Leyden, D.P., Link, A.N., Bozeman, B., 1989. The effects of governmental financing on firms' R\&D activities: a theoretical and empirical investigation. Technovation 9, $561-575$.

Leydesdorff, L., Etzkowitz, H., 1998. The triple helix as a model for innovation studies. Sci. public policy 25 (3), 195-203.

Lichtenthaler, U., Ernst, H., 2006. Attitudes to externally organising knowledge management tasks: a review, reconsideration and extension of the NIH syndrome. RD Manag. 36, 367-386.

Lindegaard, S., 2010. The Open Innovation Revolution: Essentials, Roadblocks, and Leadership Skills. John Willey \& Sons, New Jersey, USA.

Lisboa, M.B., Latif Z.A., 2013. Brazil: democracy and growth. Democracy Works Conference, Rio de Janeiro.

Love, J.H., Roper, S., 2009. Organizing innovation: complementarities between crossfunctional teams. Technovation 29, 192-203.

Love, J.H., Roper, S., Bryson, J.R., 2011. Openness, knowledge, innovation and growth in UK business services. Res. Policy 40, 1438-1452.

Matias-Pereira, J., Kruglianskas, I., 2005. Innovation management: the law of technological innovation as a tool to support industrial and technological policies in Brazil. RAE Eletrônica 4.

Markham, S.K., Griffin, A., 1998. The breakfast of championship: associations between champions and product developments environments, practices and performances. J. Product. Innov. Manag. 15, 436-454.

Matthews, L.M., 2017. Applying multigroup-analysis in PLS-SEM: a step-by-step process. In: Latan, H., Noonan, R. (Eds.), Partial Least Squares Path Modeling: Basic Concepts, Methodological Issues and Application. Springer International Publishing, Cham, pp. 219-243.

Mazzucato, M., 2011. The Entrepreneurial State. Demos, London, UK.

Mol, M.J., Birkinshaw, J., 2014. The role of external involvement in the creation of management innovations. Organ. Stud. 35, 1287-1312.

Nagano, M., S., Stefanovitz, J.P., Vick, T.E., 2014. Innovation management processes, their internal organizational elements and contextual factors: an investigation in Brazil. J. Eng. Technol. Manag. 33, 63-92.

Nassimbeni, G., 2003. Local manufacturing systems and global economy: are they compatible? The case of the Italian eyewear district. J. Oper. Manag. 21, 151-171.

Nonaka, I., Von Krogh, G., 2009. Perspective-tacit knowledge and knowledge conver-sion: controversy and advancement in organizational knowledge creation theory. Organ.
Sci. 20, 635-652.

Nunnally, J.C., Bernstein, I.H., 1994. Psychometric Theory, 3rd ed. McGraw-Hill, New York.

Oakley, R.P., 2012. Open innovation and its relevance to industrial research and development: the case of high-technology small firms. Int. Small Bus. J. 31, 319-336.

OECD, 2005. Oslo Manual: The Measurement of Scientific and technological Activities Proposed Guidelines for Collecting and Interpreting Technological Innovation Data. Ozman, M., 2012. Modularity, industry life cycle and open innovation. J. Technol. Manag. Innov. 6, 26-37.

Parida, V., Westerberg, M., Frishammar, J., 2012. Inbound open innovation activities in high-tech SMEs: the impact on innovation performance. J. Small Bus. Manag. 50, 283-309.

Piller, F.T., Walcher, D., 2006. Toolkits for idea competitions: a novel method to integrate users in new product development. RD Manag. 36, 307-318.

Randhawa, K., Wilden, R., Hohberger, J., 2016. A bibliometric review of open innovation: setting a research agenda. J. Product. Innov. Manag. 33, 750-772.

Reagans, R.E., Zuckerman, E.W., 2008. Why knowledge does not equal power: the network redundancy trade-off. Ind. Corp. Change 17, 903-944.

Ringle, C.M., Wende, S., Becker, J.-.M., 2015. 'SmartPLS 3.' Boenningstedt: SmartPLS $\mathrm{GmbH},\langle$ http://www.smartpls.com〉.

Ritala, P., Olander, H., Michailova, S., Husted, K., 2015. Knowledge sharing, knowledge leaking and relative innovation performance: an empirical study. Technovation 35, 22-31.

Rocha, R.S., 2009. Changing the (im)balance of power: high-performance work systems in Brazil. Empl. Relat. 32, 74-88.

Rocha, R.S., 2010. Shop stewards as coordinators of employee-driven innovation: implications for trade unions. Transf.: Eur. Rev, Labour Res. 16, 185-196.

Rubera, G., Chandrasekaran, D., Ordabini, A., 2016. Open innovation, product portfolio innovativeness and firm performance: the dual role of new product development capabilities. J. Mark. Sci. 44, 166-184.

Salter, A., Criscuolo, P., Ter Wal, A.L.J., 2014a. Coping with open innovation: responding to the challenges of external engagement in R\&D. Calif. Manag. Rev. 56, 77-94.

Salter, S.F., Mohr, J.J., Sengupta, S., 2014b. Radical product innovation capability: literature review, synthesis, and illustrative research propositions. J. Product. Innov. Manag. 31, 552-566.

Samson, D., Gloet, M., 2015. Innovation capability in Australian manufacturing organisations: an exploratory study. Int. J. Prod. Res. 52, 6448-6466.

Sarstedt, M., Henseler, J., Ringle, C.M., 2011. Multigroup analysis in partial least squares (PLS) path modeling: alternative methods and empirical results. In: Sarstedt, M., Schwaiger, M., Taylor, C.R. (Eds.), Advances in International Marketing 22. Emerald Group Publishing Limited, pp. 195-218.

Savage, N., 2015. In tight times, companies fill the funding gap. Cell 161, 699-701.

Sebrae, 2013. Critérios de classificação de empresas: EI - ME - EPP. 〈http://www.sebraesc.com.br/leis/default.asp?Vcdtexto $=4154\rangle$. (Accessed online July 2013).

Shane, S.A., Ulrich, K.T., 2004. Technological innovation, product development, and entrepreneurship in management science. Manag. Sci. 50, 133-144.

Sofka, W., Grimpe, C., 2010. Specialized search and innovation performance - evidence across Europe. RD Manag. 40, 310-323.

Spithoven, A., Clarysse, B., Knockaert, M., 2010. Building absorptive capacity to organise inbound open innovation in traditional industries. Technovation 30, 130-141.

Stam, W., 2009. When does community participation enhance the performance of open source software companies? Res. Policy 38, 1288-1299.

Teece, D.J., 2007. Explicating dynamic capabilities: the nature and microfoundations of (sustainable) enterprise performance. Strateg. Manag. J. 28, 1319-1350.

Teirlinck, P., Spithoven, A., 2013. Research collaboration and R\&D outsourcing: different R\&D personnel requirements in SMEs. Technovation 33, 142-153.

Tödtling, F., Lehner, P., Kaufmann, A., 2009. Do different types of innovations rely on specific kinds of knowledge interactions? Technovation 29, 59-71.

Trott, P., Hartmann, H., 2009. Why 'Open Innovation' is old wine in new bottles. Int. J. Innov. Manag. 13, 715-736.

Van de Ven, A.H.,, Harold, A.L., Poole, M.S., 2000. Research on the Management of Innovation. The Minnesota Studies, Oxford, NY.

Van de Vrande, V., Jeroen, P.J., Wim, V., Rochemont, M., 2009. Open innovation in SMEs: trends, motives and management challenges. Technovation 29, 423-437.

Von Hippel, E., 1986. Lead users: a source of novel products concepts. Manag. Sci. 32, 791-805.

Veryzer, R.W., 1998. Discontinuous innovation and the new product development process. J. Product. Innov. Manag. 15, 304-321.

West, J., Bogers, M., 2014. Leveraging external sources of innovation: a review of research on open innovation. J. Product. Innov. Manag. 31, 814-831. 